\title{
Prediction of scour at abutments using piecewise regression
}

Amir Etemad-Shahidi PhD

Senior Lecturer, Griffith School of Engineering, Griffith University, Southport, Queensland, Australia

\author{
Mohammad Sadegh Rohani MSc \\ School of Civil Engineering, Iran University of Science and Technology, \\ Tehran, Iran
}

Scour is one of the main causes of bridge failure and scour depth prediction is thus a very important issue. Although many studies have been carried out to develop formulas for the prediction of scour depth at abutments, the existing formulas do not yield accurate results, mainly due to the complexity of the scour phenomena around abutments. This paper reports on a study of abutment scour using piecewise multiple linear regression analysis. First, scour depth data were collected from the literature and the existing formulas were evaluated and compared. To develop new formulas, the conventional governing parameters were selected as the independent variables. The piecewise multiple linear regression technique was applied to investigate the relationship between dimensionless scour depth and the governing dimensionless parameters in several subdomains. Errors of the proposed formula and previous models were also compared. Compared with existing formulas, the error measures in the proposed method show a significant improvement in prediction accuracy.

$\begin{array}{ll}\text { Notation } \\ d_{50} \quad \text { median size of sediment } \\ F_{\mathrm{c}} & V_{\mathrm{c}} /(\Delta l g)^{1 / 2} \\ \mathrm{Fr} & V /(y \boldsymbol{g})^{1 / 2} \\ \boldsymbol{g} & \text { gravitational acceleration } \\ I_{\mathrm{a}} & \text { index of agreement } \\ K_{\mathrm{d}} & \text { sediment size factor } \\ K_{\mathrm{G}} & \text { channel geometry factor } \\ K_{\mathrm{I}} & \text { flow intensity factor } \\ K_{\mathrm{S}} & \text { shape factor } \\ K_{y l} & \text { abutment length or flow depth factor } \\ K_{\theta} & \text { angle of attack factor } \\ K_{\sigma} & \text { sediment gradation factor } \\ k & \text { number of independent variables } \\ l & \text { abutment length } \\ n & \text { number of measurements } \\ V & \text { flow velocity } \\ V_{\mathrm{c}} & \text { critical flow velocity } \\ \bar{x} & \text { mean of measured values } \\ x_{i} & \text { measured value } \\ y & \text { flow depth } \\ \bar{y} & \text { mean of the predicted values } \\ y_{i} & \text { predicted value } \\ y_{\mathrm{s}} & \text { equilibrium scour depth } \\ \theta & \text { angle of abutment alignment } \\ \sigma_{\mathrm{g}} & \text { geometrical standard deviation } \\ & \end{array}$

\section{Introduction}

A bridge is arched over a river, valley or crossing to enable transport. Scour is one of the main causes of bridge failure around the world. When an abutment is placed on an erodible bed, the flow pattern around the abutment will change. A change in flow field creates vortices and these vortices may finally result in scouring around the abutment. Scour is a complex phenomenon because it is the result of interaction between the fluid, the structure and sediment (Zhao and Fernando, 2007). The prediction of scour depth at the equilibrium stage is vital in the design of bridge abutments.

Many researchers have studied abutment scour, including Ahmad (1953); Dey and Barbhuiya (2004b); Froehlich (1989); Garde et al. (1961); Gill (1972); Kwan (1984); Laursen (1963); Liu et al. (1961); Melville (1992, 1997); Muzzammil (2010); and Richardson and Davis (1995). Most of these researchers used dimensionless parameters and laboratory experimental data to develop formulas for scour depth prediction.

Froehlich (1989) showed that scour depth is a function of the abutment length, flow depth, Froude number, abutment shape and abutment alignment. The US Federal Highway Administration (FHWA) suggests Froehlich's formula for short abutments and Hire's formula for long abutments (Richardson and Davis, 1995, 2001). Hire's formula implies that scour depth is a function of Froude number, abutment shape and abutment alignment. Melville (1992) developed a method to estimate the scour depth at abutments utilising different coefficients to consider the effects of abutment length, sediment size, sediment gradation and channel geometry on scour depth. Dey and Barbhuiya (2004b) investigated the scour depth formula for different abutments and showed that the scour depth also depends on the critical Froude number. 


\section{Offprint provided courtesy of www.icevirtuallibrary.com Author copy for personal use, not for distribution}

Muzzammil (2010) used artificial neural networks and adaptive neuro fuzzy system models (Haykin, 1999; Kazeminezhad et al., 2005) to increase the accuracy of the scour depth prediction. However, these soft computing methods are not transparent and are not easy for engineers either to understand and/or use.

The main purposes of this study are to compare the performances of different existing empirical methods and to develop a new set of formulas for predicting scour depth in various conditions. The presented formulas were developed using piecewise multiple linear regression by SPSS software (Levesque, 2007).

\section{Scour at abutments}

There are two conditions for local scour: clear-water and livebed. Clear-water scour occurs when there is no movement of the bed material in the upstream. Live-bed scour occurs when bed material is transported from the upstream into the scour hole (Richardson and Davis, 2001). Recent studies of abutment scour (e.g. Kwan, 1988; Kwan and Melville, 1994) have shown that the scour mechanism at abutments is very complex. The down flow and the principal vortex at the upstream corner of the abutment, together with the secondary and wake vortices at the middle part and the downstream corner of the abutment, cause complex interactions between the fluid and the bed material leading to the scour at abutments.

Previous investigations have shown that the abutment scour depth is related to parameters such as the approach flow velocity and critical flow velocity. The ratio between these two velocities can be used as an indicator for clear-water or live-bed scour conditions. If the mean velocity is equal to or less than the critical velocity of the median diameter of the bed material, then scour will be clear-water scour. If the mean velocity is greater than the critical velocity, live-bed scour will occur. The equation to determine the critical velocity for a given flow depth and size of bed material is given by Richardson and Davis (2001). The abutment length and flow depth are two other important parameters that also influence scour depth.

To consider the effects of sediment size on scour, it is important to distinguish between clear-water and live-bed conditions. Under live-bed conditions, Laursen (1960) argued that there is no significant effect of sediment size on the local scour. For clearwater conditions, studies such as those of Laursen (1960) have shown that sediment size affects local scour. Wong (1982) showed that, under clear-water conditions, scour depth increases with an increase in sediment size. However, Ahmad (1953), Izzard and Bradley (1958) and Laursen and Toch (1956) stated that scour depth is independent of sediment size.

A river's bed materials are generally non-uniform. A measure of the non-uniformity of the sediment is the geometrical standard deviation. Sediment gradation reduces scour depth with the formation of armour layers in the scour holes. It has been noticed that, when a protective layer (known as the armour layer) develops on the bed surface, sediments of all sizes are not in motion. This means, once an armour layer has been formed on the river bed, further erosion of the river bed becomes very difficult. However, finer sediment particles from tributaries may be delivered to the downstream over the armour layer. Dey and Barbhuiya (2004c) conducted experiments to study the effects of a thin armour layer on the scour depth at abutments. They concluded that the scour depth at abutments with an armour layer in clear-water scour conditions is always greater than that of the case of no armour layer for the same bed sediments (Dey and Barbhuiya, 2004a).

The local scour depth also depends on the shape of the abutment. Streamlined bodies, such as semi-circular (SC), spill-through and wing-wall (WW) abutments, produce vortices of feeble strength while blunt obstructions, such as vertical-wall (VW) abutments, are capable of producing stronger turbulent vortices. Consequently, a relatively larger scour depth is observed at blunt obstructions (Dey and Barbhuiya, 2004a). The effect of shape is expressed by the shape factor (Table 1). In addition, the abutment alignment or angle of attack, defined as the angle of the abutment axis with respect to the approaching flow direction, significantly influences the scour depth. For an abutment angled downstream, the scour depth decreases, whereas the scour depth increases for an abutment angled upstream. Richardson and Davis (2001) expressed the effect of angle by $K_{\theta}$

$$
\text { 1. } K_{\theta}=(\theta / 90)^{0 \cdot 13}
$$

where $\theta$ is the angle of attack: $\theta<90^{\circ}$ if the abutment points downstream and $\theta>90^{\circ}$ if the abutment points upstream.

\section{Description of datasets}

Several researchers have carried out experiments on abutment scour. This study used the experimental datasets of Abou Seida et al. (2009), Coleman et al. (2003), Cunha (1975), Dey and Barbhuiya (2004b), Dongol (unpublished abutment scour data, 1990), Dongol (1994), Garde et al. (1963), Gill (1972), Kandasamy (1989), Kwan (1984), Kwan (1988), Ladage (1998), Lim (1997), Liu et al. (1961), Rajaratnam and Nwachukwu (1983) and Tey (1984). In total, 827 data points were collected and the dataset is a collection of various experimental conditions; it was assumed that an equilibrium state was achieved in all the experiments. Table 2

$\begin{array}{lc}\text { Abutment shape } & K_{\mathrm{s}} \\ \text { Vertical wall } & 1.00 \\ \text { Vertical-wall abutment with semi-circular end } & 0 \cdot 75 \\ 45^{\circ} \text { wing-wall } & 0 \cdot 75 \\ \text { Spill-through }(H: V=0 \cdot 5: 1) & 0 \cdot 60 \\ \text { Spill-through }(H: V=1: 1) & 0 \cdot 50 \\ \text { Spill-through }(H: V=1 \cdot 5: 1) & 0 \cdot 45\end{array}$

Table 1. Shape factors for different abutments (Melville, 1992) 


\begin{tabular}{|c|c|c|c|c|c|c|}
\hline & $\begin{array}{l}\text { Number of } \\
\text { data points }\end{array}$ & Abutment type & $d_{50}: \mathrm{mm}$ & $\sigma_{\mathrm{g}}$ & $V I V_{c}$ & $\| y$ \\
\hline Abou Seida et al. (2009) & 24 & VW & - & - & $0.33-0.95$ & $0.62-1.27$ \\
\hline Coleman et al. (2003) & 68 & VW & $0.80-1.02$ & - & $0.46-0.99$ & $0.25-151 \cdot 3$ \\
\hline Cunha (1975) & 7 & VW & $1 \cdot 6-5 \cdot 8$ & - & $0.45-0.94$ & $2 \cdot 2$ \\
\hline Garde et al. (1963) & 7 & VW & $0 \cdot 3-1$ & - & $0 \cdot 83-2 \cdot 15$ & $1.23-2.06$ \\
\hline Gill (1972) & 23 & VW & 0.9 & $1 \cdot 2$ & $0.65-1.49$ & $1.96-8.82$ \\
\hline Kwan (1984) & 19 & VW & $0.85-0.9$ & $1 \cdot 3$ & $0.9-1$ & $1 \cdot 64-28$ \\
\hline Ladage (1998) & 4 & VW & $0 \cdot 8$ & - & $0 \cdot 49-0 \cdot 7$ & 0.75 \\
\hline $\operatorname{Lim}(1997)$ & 11 & VW & 0.94 & 1.25 & $0.41-0.74$ & $0.33-1$ \\
\hline Liu et al. (1961) & 4 & VW & $0.56-0.64$ & $1 \cdot 17$ & $0.5-0.94$ & $2-3 \cdot 75$ \\
\hline Rajaratnam and & 6 & VW & 1.4 & $1 \cdot 3$ & $0.4-0.67$ & $0.99-1.43$ \\
\hline \multicolumn{7}{|l|}{ Nwachukwu (1983) } \\
\hline Kandasamy (1989) & 30 & WW & 0.9 & $1 \cdot 3$ & $0.95-2 \cdot 25$ & $1-69$ \\
\hline Kwan (1988) & 5 & WW & 0.9 & $1 \cdot 3$ & 1 & $2 \cdot 4-9 \cdot 5$ \\
\hline Tey (1984) & 8 & VW-SC & $0.8-0.9$ & 1.26 & $0 \cdot 78-1$ & $1.65-6$ \\
\hline Dongol (unpublished 1990) & 46 & VW-WW & 0.9 & $1 \cdot 3$ & $1-6 \cdot 4$ & $0.25-1.5$ \\
\hline Dongol (1994) & 116 & VW-WW & $0.9-1.8$ & 1.3 & $0.76-4$ & $0.25-151 \cdot 3$ \\
\hline Dey and Barbhuiya (2004b) & 449 & VW-WW-SC & $0 \cdot 26-3 \cdot 1$ & $1 \cdot 17-3.73$ & 0.95 & $0 \cdot 16-2 \cdot 4$ \\
\hline TOTAL & 827 & & $0 \cdot 26-5 \cdot 8$ & $1 \cdot 17-3 \cdot 73$ & $0.33-6 \cdot 4$ & $0.16-151 \cdot 3$ \\
\hline
\end{tabular}

Table 2. Summary of test conditions in different experimental works

summarises the test conditions in different studies. The range of $l / y$ shows that the dataset includes both short and long abutments. The range of $V / V_{\mathrm{c}}$ shows that the data points were collected in both clear-water and live-bed conditions. In addition, the range of $\sigma_{\mathrm{g}}$ shows that most of the experiments were conducted using uniform sediments and the $d_{50}$ ranges indicate that both fine and coarse sediments were studies. In addition, 100 field measurements collected by Lombard and Hodgkins (2008) from different bridges were used in this study.

\section{Analysis of existing formulas}

The existing formulas of scour depth prediction and their limitations are as follows.

The FHWA method (Richardson and Davis, 2001) suggests

2. $y_{\mathrm{s}} / y=2 \cdot 27 K_{\mathrm{s}} K_{\theta}(l / y)^{0 \cdot 43} \mathrm{Fr}^{0 \cdot 61}+1$ for $l / y<25$

3. $y_{\mathrm{s}} / y=(4 / 0 \cdot 55) K_{\mathrm{s}} K_{\theta} \mathrm{Fr}^{0.33}$ for $l / y>25$

Melville (1992) proposed

4. $y_{\mathrm{s}}=K_{y l} K_{\mathrm{I}} K_{\mathrm{d}} K_{\sigma} K_{\mathrm{s}} K_{\theta} K_{\mathrm{G}}$

Dey and Barbhuiya (2004b) proposed the following (for $l / y<1$ ) vertical

5a. $\quad y_{\mathrm{s}} / l=5 \cdot 857 F_{\mathrm{c}}^{0 \cdot 314}(y / l)^{0 \cdot 126}\left(l / d_{50}\right)^{-0 \cdot 167}$

$45^{\circ}$ wing-wall

5b. $\quad y_{\mathrm{s}} / l=6 \cdot 4547 F_{\mathrm{c}}^{0 \cdot 312}(y / l)^{0 \cdot 101}\left(l / d_{50}\right)^{-0 \cdot 231}$

semi-circular

5c. $\quad y_{\mathrm{s}} / l=7 \cdot 287 F_{\mathrm{c}}^{0 \cdot 192}(y / l)^{0 \cdot 103}\left(l / d_{50}\right)^{-0 \cdot 296}$

Sensitivity analysis aims to describe how much model output values are affected by changes in the input values. The discrepancy ratio (DR), defined as the ratio of predicted and measured values, was used to quantify the sensitivity of different formulas to different variables. A DR value of 1 indicates a perfect agreement, while values greater (or smaller) than 1 show over (or under) estimation of the scour depth.

First, DR was plotted against the logarithm of $l / y$ (or relative length of the abutment). The results of the FHWA method (Froehlich formula for short abutments and Hire formula for long abutments) are shown in Figure 1(a). The mean, maximum and minimum DR values of these formulas are $2 \cdot 21,7 \cdot 28$ and $0 \cdot 32$, 


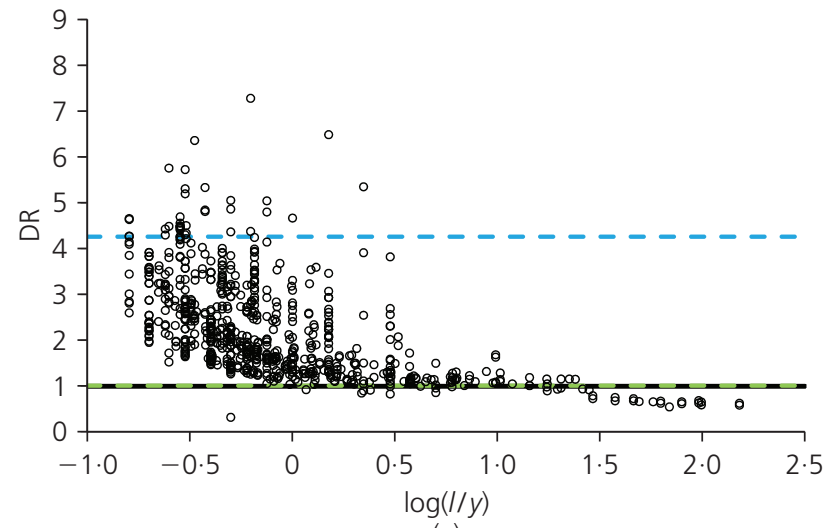

(a)

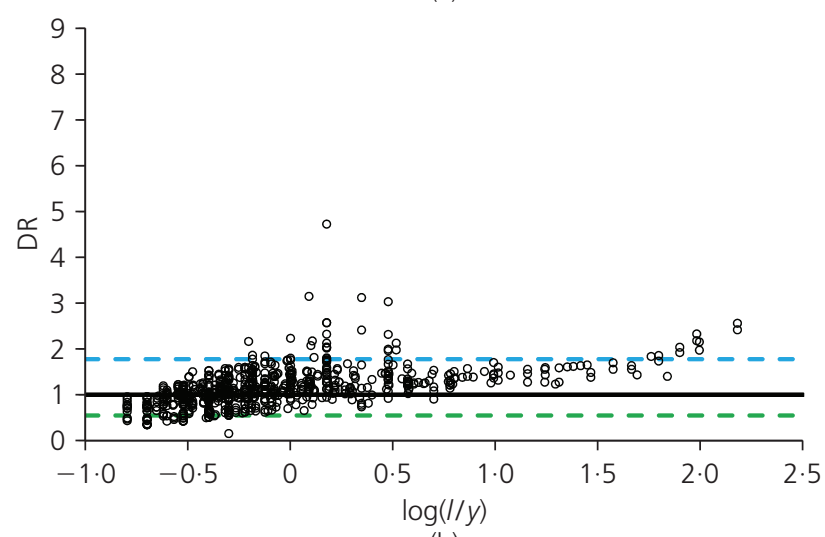

(b)

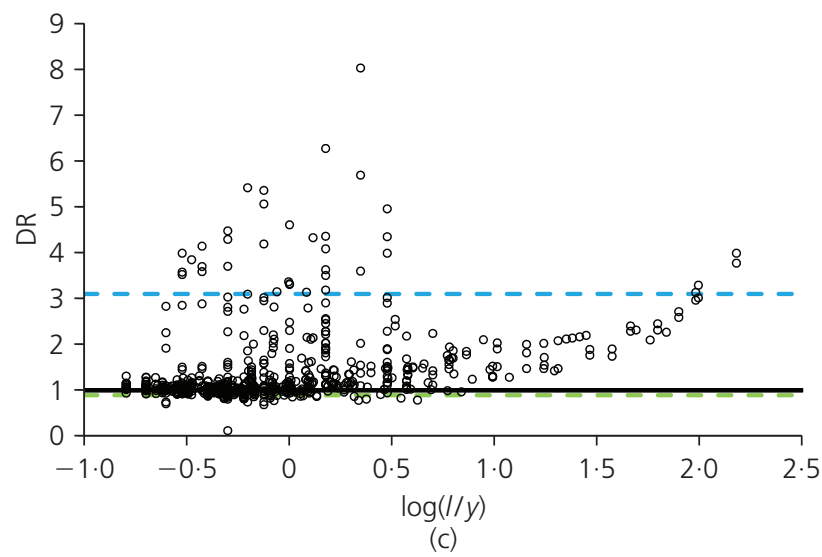

Figure 1. Variation of DR with $\log (/ / y)$ for (a) FHWA, (b) Melville (1997) and (c) Dey and Barbhuiya (2004b) formulas. The dashed lines show the $5-95 \%$ confidence interval

respectively. With an increase in $l / y$, the DR decreases and becomes less than 1. Generally, the predictions using these formulas are overestimated, especially at low values of $l / y$. This is because they are design formulas and must have an inherent safety factor. The results using the method of Melville (1997) are shown in Figure 1(b). The DR varies from 0.16 to 4.7 with a mean value of $1 \cdot 14$. With an increase of $l / y$, the accuracy of prediction reduces and the predictions become overestimated. However, this formula is accurate at low values of $l / y$. Figure 1(c) depicts the results from the Dey and Barbhuiya (2004b) formula. The mean, maximum and minimum DR values of this formula are $1.38,8.03$ and 0.12 , respectively; the accuracy of prediction is reduced for both low and high values of $l / y$. This formula is not accurate at high values of $l / y$ because it is suggested for very short abutments $(l / y<1)$. Similar to the previous methods, the formula is conservative in most cases.

In the second step, DR was plotted against the logarithm of $V / V_{\mathrm{c}}$ (Figure 2). Figure 2(a) shows that, by increasing $V / V_{\mathrm{c}}$ (in live-bed

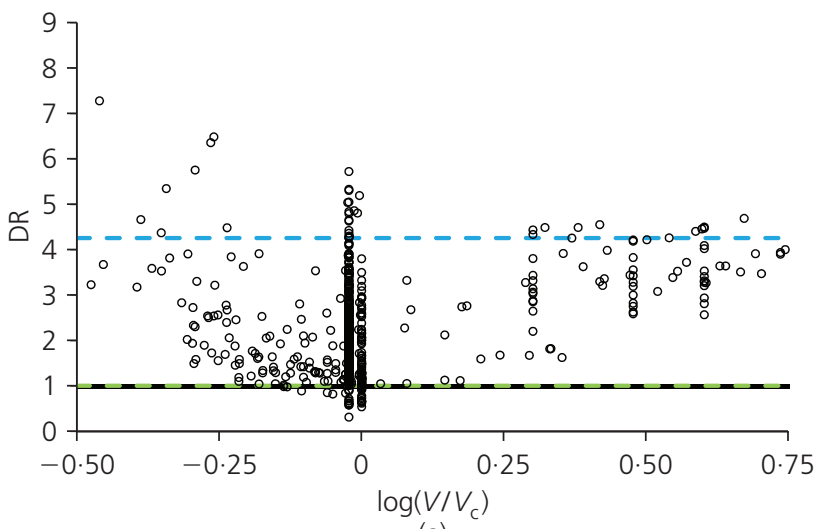

(a)

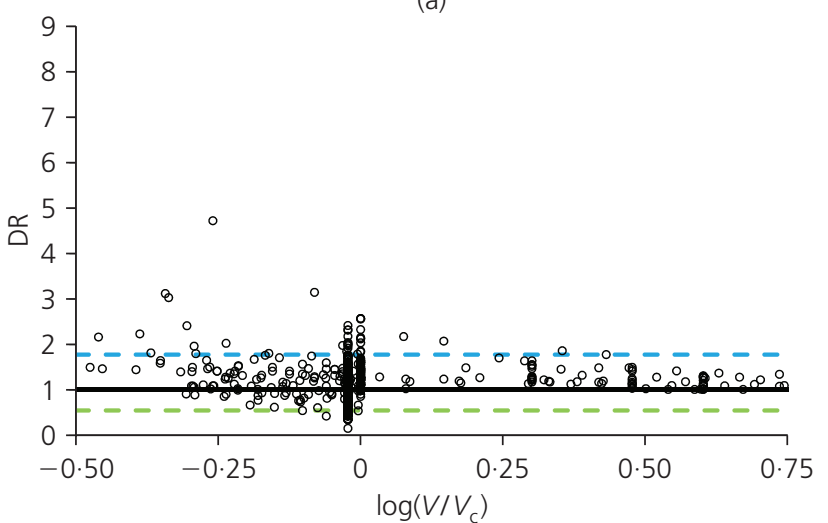

(b)

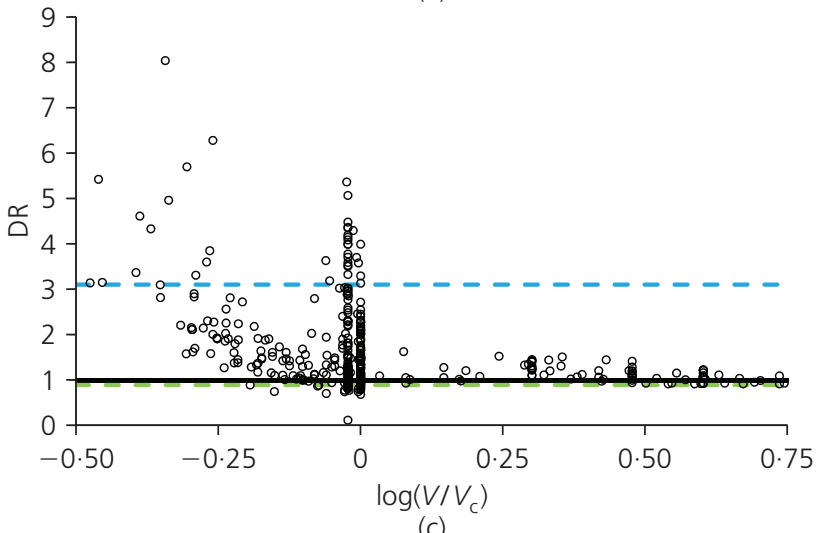

(c)

Figure 2. Variation of DR versus log $\left(V I V_{c}\right)$ for (a) FHWA, (b) Melville (1997) and (c) Dey and Barbhuiya (2004b) formulas. The dashed lines show the 5-95\% confidence interval 
conditions), the accuracy of prediction is reduced when using the FHWA method. The formula of Melville (1997) (Figure 2(b)) is more accurate in the clear-water condition than the other formulas and yields acceptable results for live-bed conditions. The results of the Dey and Barbhuiya (2004b) formula are shown in Figure 2(c). Interestingly, this formula performs well in livebed conditions, even though it was developed for the clear-water condition. This is mainly due to the fact that it was derived from experiments with $V / V_{\mathrm{c}}=0.95$. In brief, the FHWA method and the Dey and Barbhuiya (2004b) formulas overestimate the scour depth for very low values of $V / V_{\mathrm{c}}$ because $V / V_{\mathrm{c}}$ is not considered in these formulas. In clear-water condition, flow velocity is much less than the critical velocity and the scour depth is minimal.

\section{Development of new formulas}

The most important task in developing new scour depth formulas is to find the most reliable parameters to be included in the formula. The influential parameters on equilibrium scour depth at an abutment are generally expressed in the following functional form, assuming a constant relative density of sediment and the absence of viscous effects

$$
\text { 6. } y_{\mathrm{s}}=f\left(y, l, g, V, V_{\mathrm{c}}, \sigma_{\mathrm{g}}, K_{\mathrm{s}}, K_{\theta}\right)
$$

In the empirical approaches, parameters involved in abutment scour are correlated through dimensional analysis, and different combinations of these parameters were used for developing the formulas. Here, the simplest and most accurate formulas are presented. As previous studies have shown, the most important dimensionless parameters are $l / y, \mathrm{Fr}, V / V_{\mathrm{c}}, \sigma_{\mathrm{g}}, K_{\mathrm{s}}$ and $K_{\theta}$, and these parameters were thus used in the new formulas. Equation 6 may be reduced, in terms of a set of non-dimensional parameters, to

7. $y_{\mathrm{s}} / y=f\left(l / y, \mathrm{Fr}, V / V_{\mathrm{c}}, \sigma_{\mathrm{g}}, K_{\mathrm{s}}, K_{\theta}\right)$

A power-law form of Equation 7 may be expressed as

8. $y_{\mathrm{s}} / y=a(l / y)^{b} \operatorname{Fr}^{c}\left(V / V_{\mathrm{c}}\right)^{d} K_{\mathrm{s}}$

where $a$ is a coefficient and $b, c$ and $d$ are exponents of the equation.

The effects of sediment non-uniformity will be discussed later because the sediments were uniform in this dataset and variations in $\sigma_{\mathrm{g}}$ were very small. In addition, the effect of sediment diameter was found to be negligible and was excluded from the formula. $K_{\theta}$ was also equal to 1 in all of the data points.

Piecewise regression was used to derive the formulas. Piecewise regression is similar to the decision-tree method and a multivariable function is suggested at each leaf for output. Noting the difference between live-bed and clear-water conditions, the dataset was first divided into two parts: $V / V_{\mathrm{c}}>1$ and $V / V_{\mathrm{c}}<1$. Then, a multiple linear regression model was developed for each condition. The multiple linear regression technique was applied to develop the relationship between the dependent variable and several independent variables in Equation 8. Datasets were divided into two parts for training and testing the formulas. Accurate results for training data do not necessarily guarantee the generalisation capability of the proposed formula. The performance of the developed formula should always be checked with the testing data (Haykin, 1999). To develop the formulas, 747 data points were used (663 for clear-water conditions and 84 for livebed conditions); $70 \%$ were used for training and the remaining $30 \%$ for testing the formulas. Equations $9 a$ and $9 b$ (called PR1) were obtained using SPSS software

$$
y_{\mathrm{s}} / y=1 \cdot 85(l / y)^{0.397} \operatorname{Fr}^{0 \cdot 134}\left(V / V_{\mathrm{c}}\right)^{0.859} K_{\mathrm{s}}
$$

9a. for $V / V_{\mathrm{c}}<1$

$$
y_{\mathrm{s}} / y=1 \cdot 1(l / y)^{0 \cdot 422} \operatorname{Fr}^{0 \cdot 182}\left(V / V_{\mathrm{c}}\right)^{0 \cdot 136} K_{\mathrm{s}}
$$

9b. for $V / V_{\mathrm{c}}>1$

The set of equations PR1 shows the dependency of scour depth on $l / y, \mathrm{Fr}, V / V_{\mathrm{c}}$ and abutment shape. PR1 implies that scour depth increases significantly with an increase in $l / y$. The powers of $l / y$ in both formulas are also close to that in the Froehlich (1989) formula. This finding is also supported by the previous findings of Liu et al. (1961). The scour depth moderately increases with an increase in Fr in PR1. The powers of Fr in both formulas are less than that of other formulas such as Froehlich (1989) and Hire (Richardson and Davis, 1995). This can be justified by noting that, in the previous formulas, the effect of velocity is considered in one parameter (Fr or $V / V_{\mathrm{c}}$ ). However, in PR1, both Fr and $V / V_{\mathrm{c}}$ are considered, and the effect of approaching flow is included in both Fr and $V / V_{\mathrm{c}}$. Hence, the power of $\mathrm{Fr}$ reduces. The main difference in clear-water and live-bed conditions is in the transport of the upstream sediments, which depends on $V / V_{\mathrm{c}}$. The main splitting value in PR1 is $V / V_{\mathrm{c}}=1$. This shows that PR1 classifies the dataset into two parts: $V / V_{\mathrm{c}}<1$, which is the clearwater condition, and $V / V_{\mathrm{c}}>1$, which is the live-bed condition. The power of $V / V_{\mathrm{c}}$ is 0.859 in Equation $9 \mathrm{a}$, showing that, in the clear-water condition, $V / V_{\mathrm{c}}$ is an important parameter. However, in the live-bed condition $\left(V / V_{\mathrm{c}}>1\right), V / V_{\mathrm{c}}$ is not as important, and its power decreases. This is in line with the findings of Melville (1992), where the power of $V / V_{\mathrm{c}}$ is one for clear-water and zero for live-bed conditions. $K_{\mathrm{s}}$ was also obtained from Table 1. It can thus be said that the PR1 formulas are physically sound and are successful in capturing the relationships among the dimensionless scour parameters.

Figure 3, which compares the measured scour depths and those 


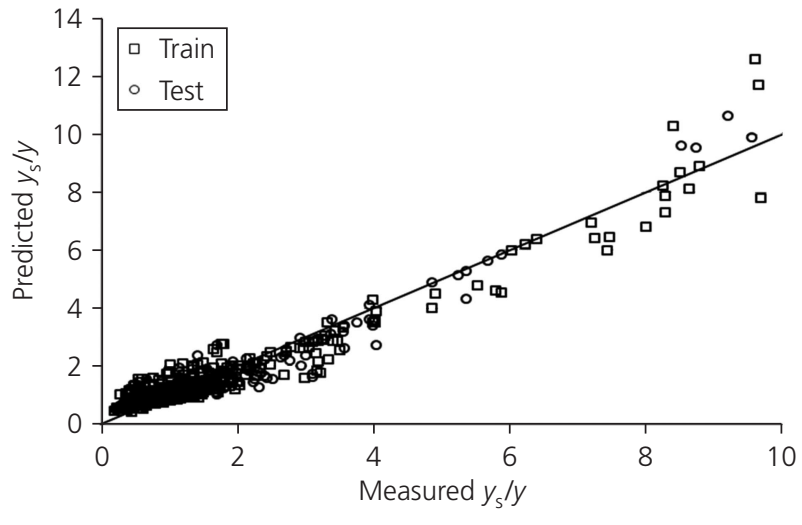

Figure 3. Comparison of measured and predicted dimensionless scour depths

predicted by PR1 (all data points), shows that most of the data points are concentrated on the line of perfect agreement. At very high values of $y_{\mathrm{s}} / y, \mathrm{PR} 1$ overestimates the dimensionless scour depth. However, the overestimation in these cases is marginal and negligible. For a quantitative comparison between the predicted and measured scour depth values, error measures such as index of agreement $\left(I_{\mathrm{a}}\right)$, scatter index (SI) and Bias were used

10. $I_{\mathrm{a}}=1-\frac{\sum_{i=1}^{n}\left(y_{i}-x_{i}\right)^{2}}{\sum_{i=1}^{n}\left(\left|x_{i}-\bar{x}\right|+\left|y_{i}-\bar{y}\right|\right)^{2}}$

11. $\mathrm{SI}=100 \frac{\left(1 / n \sum_{i=1}^{n}\left(x_{i}-y_{i}\right)^{2}\right)^{1 / 2}}{\bar{x}}$

\section{2. $\operatorname{Bias}=\bar{y}-\bar{x}$}

Table 3 shows the error measures of PR1 and other formulas. In total, 225 data points were used to calculate the error measures. However, only 143 data points of this dataset are in the range of applicability of the Dey and Barbhuiya (2004b) formula $(l / y<1)$, and hence this formula was evaluated using only these 143 data

\begin{tabular}{lcccc}
\hline Method & $\begin{array}{c}\text { Number of } \\
\text { data points }\end{array}$ & la & SI: \% & Bias \\
& 143 & 0.78 & 34 & 0.20 \\
Dey and Barbhuiya (2004b) & 143 & 0.77 & 30 & 0.10 \\
PR1 & 225 & 0.88 & 95 & 0.42 \\
Melville (1992) & 225 & 0.81 & 49 & 0.81 \\
FHWA & 225 & 0.98 & 26 & 0.01 \\
PR1 & & & &
\end{tabular}

Table 3. Error measures of different formulas points. The SI of PR1 is reduced by $69 \%$ compared with the Melville (1992) formula and by $23 \%$ compared with the FHWA method. Moreover, the index of agreement $\left(I_{\mathrm{a}}\right)$ of PR 1 is $0 \cdot 17$ greater than that of the FHWA method and $0 \cdot 10$ greater than the Melville formula. Bias shows the over- or underestimation of formulas. The Bias of the FHWA and Melville (1992) formulas shows that the FHWA formula is more conservative than the Melville formula. The error measures for 149 data points indicate that PR1 is also more accurate than the formula proposed by Dey and Barbhuiya (2004b). In brief, the higher values of $I_{\mathrm{a}}$ and lower values of Bias and SI indicate that PR1 is more accurate than the other formulas considered. It should be mentioned that using all data for developing new formulas did not improve the accuracy of predictions significantly.

Equations $9 \mathrm{a}$ and $9 \mathrm{~b}$ were further tested for their statistical reliability and significance. An analysis of variance (Anova) approach was used to test the statistical significance of the derived formulas. To test the hypothesis claiming that the amount of variation explained by the regression model is more than the variation explained by the average, the $F$ ratio was used (Hair $e t$ al., 1995). The null hypothesis is rejected if $F_{0}>F_{\alpha, k, n-p}$. An example of the model significance test of Equations $9 \mathrm{a}$ and $9 \mathrm{~b}$ is given in Table 4 . In the $F$ distribution table with $F_{0.05}, k=4$ (number of independent variables), $p=k+1$ and $n$ is equal to 467 and 55 for Equations $9 \mathrm{a}$ and $9 \mathrm{~b}$, respectively. Therefore, $F_{0 \cdot 05,4,462}=2 \cdot 37$ for Equation $9 \mathrm{a}$ and $F_{0 \cdot 05,4,50}=2 \cdot 59$ for Equation $9 \mathrm{~b}$. However,

$$
F_{0}=\mathrm{MS}_{\mathrm{R}} / \mathrm{MS}_{\mathrm{E}}=2499 \cdot 9>F_{0 \cdot 05,4,462}
$$

for Equation $9 \mathrm{a}$ where $\mathrm{MS}_{\mathrm{R}}$ is mean square regression and $\mathrm{MS}_{\mathrm{E}}$ is mean square error and

$$
F_{0}=\mathrm{MS}_{\mathrm{R}} / \mathrm{MS}_{\mathrm{E}}=799 \cdot 5>F_{0 \cdot 05,4,50}
$$

for Equation 9b.

The null hypothesis is thus rejected for both, and the PR1 formulas are accepted as significant.

Figure 4 shows the results of PR1 (for all data). Figure 4(a) shows that, at low values of $l / y$, the predicted values are overestimated in some cases and PR1 is more accurate at high values of $l / y$. Figure 4(b) shows that at very low values of $V / V_{\mathrm{c}}$, PR1 is conservative and PR1 is more accurate in live-bed conditions.

Non-uniformity of the sediments is another influential parameter on scour depth. In Figure 5, variations of the ratio between measured and predicted (by PR1) values are plotted against $\sigma_{\mathrm{g}}$ to investigate the effect of $\sigma_{\mathrm{g}}$ on the scour depth. In Figure 5, 80 data points from the experiments of Dey and Barbhuiya (2004b) are used. In this dataset, $\sigma_{\mathrm{g}}$ varies from 1.17 to 3.73 with a mean 


\begin{tabular}{|c|c|c|c|}
\hline $\begin{array}{l}\text { Source of } \\
\text { variation }\end{array}$ & Sum of squares & $\begin{array}{l}\text { Degree of } \\
\text { freedom }\end{array}$ & Mean squares \\
\hline \multicolumn{4}{|l|}{ Equation 9a } \\
\hline Regression & $S S_{R}=2099.944$ & $k=4$ & $\mathrm{MS}_{\mathrm{R}}=\mathrm{SS}_{\mathrm{R}} / \mathrm{k}=524.98$ \\
\hline Error & $\mathrm{SS}_{\mathrm{E}}=98.71$ & $n-p=462$ & $\mathrm{MS}_{\mathrm{E}}=\mathrm{SS}_{\mathrm{E}} /(n-p)=0.21$ \\
\hline $\begin{array}{l}\text { Total } \\
\text { Equation } 9 \mathrm{~b}\end{array}$ & $S S_{Y Y}=2198.65$ & $n-1=466$ & \\
\hline Regression & $S S_{R}=63.95$ & $k=4$ & $\mathrm{MS}_{\mathrm{R}}=\mathrm{SS}_{\mathrm{R}} / \mathrm{k}=15.99$ \\
\hline Error & $\mathrm{SS}_{\mathrm{E}}=1.124$ & $n-p=50$ & $\mathrm{MS}_{\mathrm{E}}=\mathrm{SS}_{\mathrm{E}} /(n-p)=0.02$ \\
\hline Total & $S S_{Y Y}=65.08$ & $n-1=54$ & \\
\hline
\end{tabular}

Table 4. Anova table of Equations 9a and 9b. $\mathrm{SS}_{\mathrm{E}}$, error variance;

$S_{R}$, regression variance; $S S_{Y Y}$, total variance

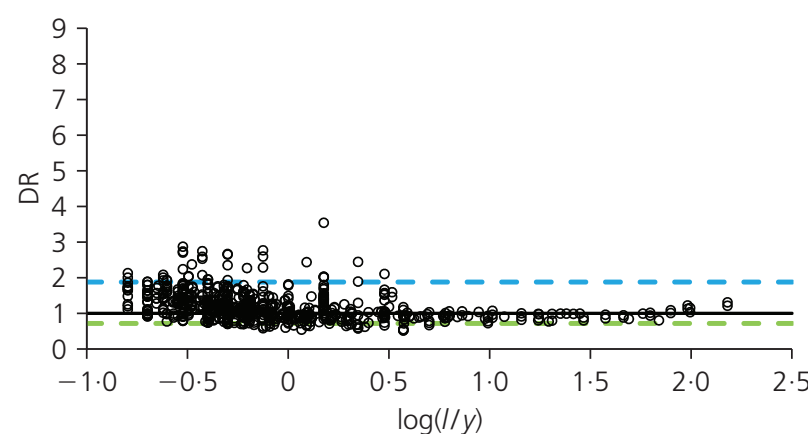

(a)

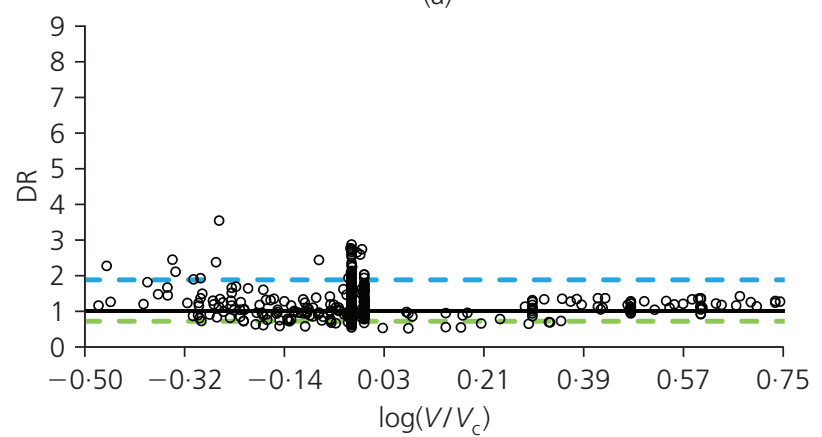

(b)

Figure 4. DR versus (a) $\log (/ / y)$ and (b) $\log \left(V / V_{c}\right)$ for PR1 (Equations $9 \mathrm{a}$ and $9 \mathrm{~b})$. The dashed lines show the 5-95\% confidence interval

value of $2 \cdot 17$. The effect of non-uniformity can be considered by $K_{\sigma}$. This factor was obtained by best fitting as
13. $K_{\sigma}=1 \cdot 41 \sigma_{\mathrm{g}}^{-1.31}$
$1 \cdot 2<\sigma_{\mathrm{g}}<3 \cdot 7$

It should be mentioned that this formula is only valid in the range of measured values and may not be extrapolated for other cases. Hence, the modified formulas (here called PR2) for non-uniform sediments will be

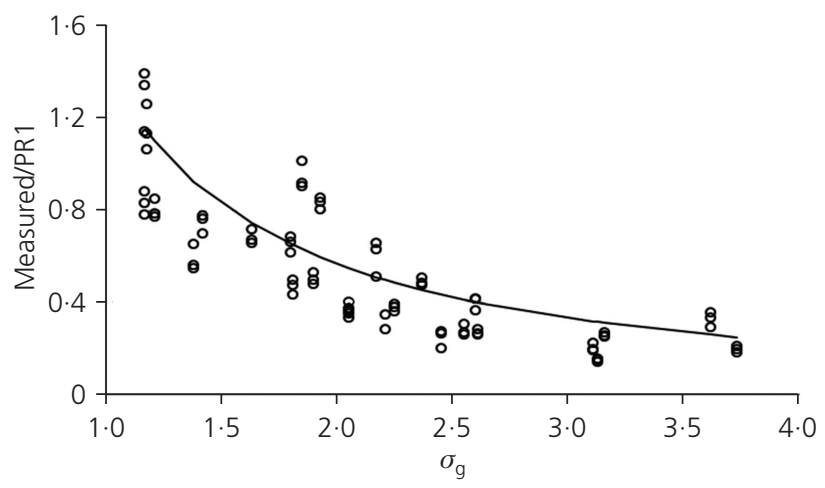

Figure 5. Variation of the ratio between measured and predicted (by PR1) scour depths against $\sigma_{\mathrm{g}}$

$$
y_{\mathrm{s}} / y=1 \cdot 85(l / y)^{0.397} \mathrm{Fr}^{0 \cdot 134}\left(V / V_{\mathrm{c}}\right)^{0 \cdot 859} K_{\mathrm{s}} K_{\sigma}
$$

14a. for $V / V_{\mathrm{c}}<1$

$$
y_{\mathrm{s}} / y=1 \cdot 1(l / y)^{0 \cdot 422} \operatorname{Fr}^{0 \cdot 182}\left(V / V_{\mathrm{c}}\right)^{0 \cdot 136} K_{\mathrm{s}} K_{\sigma}
$$

14b. for $V / V_{\mathrm{c}}>1$

Scour depth significantly decreases with increasing $\sigma_{\mathrm{g}}$. The power of $\sigma_{\mathrm{g}}$ in these formulas is equal to $-1 \cdot 31$, which means that the effects of $\sigma_{\mathrm{g}}$ are very important. This is also in line with the physics of the phenomena because, by increasing $\sigma_{\mathrm{g}}$, a stronger armour layer is formed, which prevents scouring. Dey and Barbhuiya (2004b) suggested that $K_{\sigma}$ can be determined using a graph of $K_{\sigma}$ versus $\sigma_{\mathrm{g}}$. It can be seen that the presented $K_{\sigma}$ is in agreement with the results obtained by Dey and Barbhuiya (2004b).

Table 5 shows the error measures of PR2 and the previous formulas for field data collected by Lombard and Hodgkins (2008). The $l / y$ values in this dataset vary from 0 to $244 \cdot 6$ (i.e. 


\section{Offprint provided courtesy of www.icevirtuallibrary.com Author copy for personal use, not for distribution}

\begin{tabular}{lcrrr}
\hline & Number of data points & $l_{\text {a }}$ & SI: \% & Bias \\
\hline Melville (1997) & 100 & -0.33 & 668 & 2.79 \\
FHWA & 100 & -0.28 & 353 & 1.74 \\
PR2 & 100 & 0.07 & 234 & -0.31
\end{tabular}

Table 5. Error measures of different formulas (field measurements)

the dataset includes both short and very long abutments). The range of $V / V_{\mathrm{c}}$ is $0 \cdot 05-2 \cdot 37$, meaning that the data points are in both clear-water and live-bed conditions. The range of $\sigma_{\mathrm{g}}$ is $2 \cdot 4-$ $44 \cdot 8$, showing that all sediments are non-uniform. To calculate the error measures of the different formulas, 100 data points were used. Only four data points from this dataset are in the range of applicability of the Dey and Barbhuiya (2004b) formula $(l / y<1)$, which is insufficient to calculate the error measures.

Generally, the predicted values are not in perfect agreement with the measurements, but the PR2 equations are more accurate than the other formulas. The SI of scour depths predicted by PR2 is significantly less than those of the FHWA and Melville (1997) formulas, and the $I_{\mathrm{a}}$ of PR2 is higher. The Bias of the FHWA and Melville results shows that these formulas are very conservative; the Bias of PR2 is less than that of the other two formulas and its predictions agree with the measurement. This is due to two reasons. Firstly, the other formulas do not include the effect of $V / V_{\mathrm{c}}$ on scour depth, whereas PR2, by considering $V / V_{\mathrm{c}}$, is able to predict the scour depth in both clear and live conditions. The second reason is non-uniformity of sediments. In this dataset, all the measurements were taken in non-uniform sediment, and the FHWA and Melville formulas cannot consider the effect of this on scour depth. PR2 does consider $K_{\sigma}$, and can thus predict scour depth more accurately.

Commonly used models for estimating the scour depth at the abutment typically provide conservative values (Tables 3 and 5). However, the safety factors used in them are not known, and therefore the risk of bridge failure using these formulas is unknown. This limitation can be overcome by considering a safety factor related to the desired or allowable level of risk as follows

$$
y_{\mathrm{s}} / y=\left(1 \cdot 85+N \sigma_{1}\right)(l / y)^{0.397} \operatorname{Fr}^{0 \cdot 134}\left(V / V_{\mathrm{c}}\right)^{0.859} K_{\mathrm{s}} K_{\sigma}
$$

15a. for $V / V_{\mathrm{c}}<1$

$$
y_{\mathrm{s}} / y=\left(1 \cdot 1+N \sigma_{2}\right)(l / y)^{0 \cdot 422} \operatorname{Fr}^{0 \cdot 182}\left(V / V_{\mathrm{c}}\right)^{0 \cdot 136} K_{\mathrm{s}} K_{\sigma}
$$

15b. for $V / V_{\mathrm{c}}>1$

where $N$ is the safety factor and $\sigma_{1}$ and $\sigma_{2}$ are the standard deviations ( 0.6 and 0.3 , respectively). The values of $N$ can be obtained from the normal distribution curve. For example, for $5 \%$ acceptable risk, $N$ is equal to $1 \cdot 64$.

\section{Summary and conclusions}

The scour depth at bridge abutments has been investigated. The data used for the development of new formulas were collected from previous experimental small-scale studies. The selection of input parameters has a large impact on a model's simplicity and accuracy, and hence different dimensionless parameters were used for formula development. Piecewise multiple linear regression was used to predict the dimensionless scour depth. Both live-bed and clear-water conditions were considered, and different dimensionless parameters were examined in developing the formulas. The utilised approach showed high performance for all cases, leading to reduced error measures.

PR1 (Equations 9a and 9b) was developed for uniform sediments using $l / y, \mathrm{Fr}, V / V_{\mathrm{c}}$ and $K_{\mathrm{s}}$, and the results were compared with those derived using previously proposed formulas. It was found that PR1 is physically sound and more accurate than the previous empirical formulas. PR1 was then modified to consider sediment non-uniformity, and $\sigma_{\mathrm{g}}$ was used in the modified formulas comprising set PR2 (Equations 14a and 14b). PR2 and other formulas were evaluated using field data. The results were not in perfect agreement with the measurements, but PR2 was more accurate than the other formulas considered. Finally, by considering the safety factor, design formulas were presented for the prediction of scour depth at an abutment.

\section{Acknowledgements}

We would like to thank Milad Taghipour for his help and Ian Johnson for his improvements to the manuscript.

\section{REFERENCES}

Abou Seida MM, Elsaeed GH, Mostafa TMS and Elzahry EFM (2009) Experimental investigation of abutment scour in sandy soil. Journal of Applied Sciences Research 5(1): 57-65.

Ahmad M (1953) Experiments on design and behavior of spurdikes. Proceedings of International Hydraulics Convention. ASCE, New York, USA, pp. 145-159.

Coleman SE, Lauchlan CS and Melville BW (2003) Clear-water scour development at bridge abutments. Journal of Hydraulic Research 41(5): 521-531.

Cunha LV (1975) Time evolution of local scour. Proceedings of the 16th Conference of the International Association of Hydraulic Research. IAHR, Delft, The Netherlands, pp. 285299.

Dey S and Barbhuiya AK (2004a) Local scour at abutments: a review. Sadhana 29(5): 449-476.

Dey S and Barbhuiya AK (2004b) Clear water scour at abutments. Proceedings of the Institution of Civil Engineers - Water Management 157(2): 77-97.

Dey S and Barbhuiya AK (2004c) Clear-water scour at abutments 
in thinly armored beds. Journal of Hydraulic Engineering ASCE 130(7): 622-634.

Dongol DMS (1994) Local Scour at Bridge Abutments. School of Engineering, University of Auckland, Auckland, New Zealand, Report 544.

Froehlich DC (1989) Local scour at bridge abutments. Proceedings of National Conference on Hydraulic Engineering, New Orleans, LA, USA. ASCE, New York, NY, USA, pp. 13-18.

Garde RJ, Subramanya K and Nambudripad KD (1961) Study of scour around spur-dikes. Journal of Hydraulic Division ASCE 87(6): 23-37.

Garde RJ, Subramanya K and Nambudripad KD (1963) Closure of 'Study of scour around spur-dikes'. Journal of Hydraulic Division ASCE 88(7): 167-175.

Gill MA (1972) Erosion of sand beds around spur-dikes. Journal of Hydraulic Division ASCE 98(9): 1587-1602.

Hair JF, Anderson RE, Tathan RL and Black W (1995) Multivariate Data Analysis with Readings, 4th edn. Prentice Hall, Englewood Cliffs, New Jersey, USA.

Haykin S (1999) Neural Networks: A Comprehensive Foundation. Macmillan, New York, NY, USA.

Izzard CF and Bradley JN (1958) Field verification of model tests on flow through highway bridges and culverts. Proceedings of 7th Hydraulic Conference. ASCE, Iowa, USA. pp. 225-243

Kandasamy JK (1989) Abutment Scour. School of Engineering, University of Auckland, Auckland, New Zealand, Report 458.

Kazeminezhad M, Etemad-Shahidi A and Mousavi J (2005) Application of fuzzy inference system in prediction of wave parameters. Ocean Engineering 32(14): 1709-1725.

Kwan TF (1984) Study of Abutment Scour. School of Engineering, University of Auckland, Auckland, New Zealand, Report 328.

Kwan TF (1988) A Study of Abutment Scour. School of Engineering, University of Auckland, Auckland, New Zealand, Report 451.

Kwan TF and Melville BW (1994) Local scour and flow measurements at bridge abutments. Journal of Hydraulic Research 32(5): 661-673.

Ladage F (1998) Temporal Development of Local Scour at Bridge Abutments. University of Auckland, Auckland, New Zealand, Internal report.

Laursen EM (1960) Scour at bridge crossings. Journal of Hydraulic Division ASCE 86(3): 39-54.

Laursen EM (1963) An analysis of relief bridge scour. Journal of Hydraulic Division ASCE 89(3): 93-118.

Laursen EM and Toch A (1956) Scour Around Bridge Piers and Abutments. Iowa Highways Research Board, Ames, IA, USA, Bulletin 4.

Levesque R (2007) SPSS Programming and Data Management: A Guide for SPSS and SAS Users, 4th edn. SPSS Inc., Chicago, IL, USA.

Lim SY (1997) Equilibrium clear-water scour around an abutment. Journal of Hydraulic Engineering ASCE 123(3): 237-243.

Liu HK, Chang FM and Skinner MM (1961) Effect of Bridge Construction on Scour and Backwater. Civil Engineering
Section, Colorado State University, Fort Collins, CO, USA, CER 60 HKL 22.

Lombard PJ and Hodgkins GA (2008) Comparison of Observed and Predicted Abutment Scour at Selected Bridges in Maine. U.S. Geological Survey Scientific Investigations Report 20085099. See http://pubs.usgs.gov/sir/2008/5099/ (accessed 17/ 09/2012).

Melville BW (1992) Local scour at bridge abutments. Journal of Hydraulic Engineering ASCE 118(4): 615-631.

Melville BW (1997) Pier and abutment scour: integrated approach. Journal of Hydraulic Engineering ASCE 123(2): 125-136.

Muzzammil M (2010) ANFIS approach to the scour depth prediction at a bridge abutment. Journal of Hydroinformatics 12(4): 474-485.

Rajaratnam N and Nwachukwu BA (1983) Flow near groin-like structures. Journal of Hydraulic Engineering ASCE 109(3): 463-480.

Richardson EV and Davis SR (1995) Evaluating Scour at Bridges. USDoT Federal Highway Administration, Washington, DC, USA, HEC 18.

Richardson EV and Davis SR (2001) Evaluating Scour at Bridges, 4th edn., USDoT Federal Highway Administration, Washington, DC, USA, HEC 18 FHWA NHI-001.

Tey CB (1984) Local Scour at Bridge Abutments. School of Engineering, University of Auckland, Auckland, New Zealand, Report 329.

Wong WH (1982) Scour at Bridge Abutments. School of Engineering, University of Auckland, New Zealand, Report 275.

Zhao ZH and Fernando HJS (2007) Numerical simulation of scour around pipelines using an Euler-Euler coupled two-phase model. Environmental Fluid Mechanics 7(2): 121-142.

\section{WHAT DO YOU THINK?}

To discuss this paper, please email up to 500 words to the editor at journals@ice.org.uk. Your contribution will be forwarded to the author(s) for a reply and, if considered appropriate by the editorial panel, will be published as a discussion in a future issue of the journal.

Proceedings journals rely entirely on contributions sent in by civil engineering professionals, academics and students. Papers should be 2000-5000 words long (briefing papers should be 1000-2000 words long), with adequate illustrations and references. You can submit your paper online via www.icevirtuallibrary.com/content/journals, where you will also find detailed author guidelines. 